\title{
Utilization of Bioslurry on Maize Hydroponic Fodder as a Corn Silage Supplement on Nutrient Digestibility and Milk Production of Dairy Cows
}

\author{
H. D. Nugroho ${ }^{a}$ I. G. Permana $a^{\mathrm{b}, *}$, \& Despal ${ }^{\mathrm{b}}$ \\ ${ }^{a}$ Graduate School of Animal Nutrition and Feed Science, Bogor Agricultural University \\ ${ }^{b}$ Department of Nutrition and Feed Technology, Faculty of Animal Science, Bogor Agricultural University \\ Jalan Agatis, Kampus IPB Darmaga, Bogor 16680, Indonesia \\ (Received 23-10-2014; Reviewed 05-02-2015; Accepted 13-03-2015)
}

\begin{abstract}
The research was conducted to study the effect of addition of 7\% DM maize hydroponic fodder (MHF) in corn silage on digestibility and milk production of dairy cows. The experiment used a completely randomized block design with two treatments, and four replications. The treatments were dairy cows fed with grass (Pennisetum purpureum), corn silage, and concentrate (R0), and dairy cows fed with grass ( $P$. purpureum), corn silage, concentrate, and MHF (R1). This research used eight dairy cows with initial average milk production of $13.01 \pm 2.96 \mathrm{~L} / \mathrm{d}$. MHF was produced in a hydroponic system using bioslurry as a fertilizer enriched with mineral fertilizer. Variables observed were chemical composition of bioslurry, nutrient content of ration, daily dry matter intake, nutrient digestibility, Total Digestible Nutrient (TDN), and Digestible Energy (DE). Data were analyzed with ANOVA, except for milk production using ANCOVA. Supplementation of MHF resulted a higher total dry matter intake on R1 than R0 $(\mathrm{P}<0.05), 12.99 \pm 0.063 \mathrm{~kg} / \mathrm{head} / \mathrm{d}$, and $11.98 \pm 0.295 \mathrm{~kg} / \mathrm{head} / \mathrm{d}$, respectively. The digestibility of nutrients were not affected by the addition of MHF. Energy consumption in R1 was also higher than R0 $(P<0.05)$, $49.95 \pm 0.36 \mathrm{Mkal} / \mathrm{kg}$, and $46.11 \pm 0.54 \mathrm{Mkal} / \mathrm{kg}$, respectively. Supplementation of MHF also increased nitrogen consumption, $\mathrm{R} 1$ was higher than $\mathrm{R} 0(\mathrm{P}<0.05), 318.3 \pm 2.3 \mathrm{~g} / \mathrm{head} / \mathrm{d}$, and $295.9 \pm 3.5 \mathrm{~g} / \mathrm{head} / \mathrm{d}$, respectively, and could maintain the persistency of milk production at the end of lactation. It can be concluded that supplementation of MHF in corn silage can increase dry matter intake, energy consumption, and nitrogen consumption, also can maintain nutrient digestibility and maintain persistency of milk production during late lactation of dairy cows.
\end{abstract}

Key words: bioslurry, dairy cow, greenhouse fodder, nutrient digestibility

\section{ABSTRAK}

Penelitian ini dilakukan untuk mempelajari pengaruh penambahan $7 \%$ maize hydroponic fodder (MHF) sebagai suplemen silase jagung terhadap kecernaan nutrien dan produksi susu sapi perah. Penelitian menggunakan rancangan acak kelompok (RAK) dengan 2 perlakuan dan 4 ulangan. Perlakuan pertama adalah kontrol (R0), yaitu sapi perah yang diberi pakan rumput gajah (Pennisetum purpureum), silase jagung, dan konsentrat. Perlakuan kedua adalah sapi perah yang diberi pakan rumput gajah (P. purpureum), silase jagung, konsentrat, dan 7\% MHF (R1). Sapi yang digunakan sebanyak 8 ekor dengan produksi susu awal $13.01 \pm 2.96 \mathrm{l} / \mathrm{h}$. MHF diproduksi pada sistem hidroponik menggunakan bioslurry cair yang diperkaya dengan mineral mix sebagai sumber nutrien. Parameter yang diuji adalah kandungan nutrien bioslurry cair, kandungan nutrien ransum, konsumsi bahan kering, konsumsi nutrien, kecernaan nutrien, total digestible nutrient (TDN), kecernaan energi, dan produksi susu. Data dianalisis menggunakan ANOVA, kecuali peubah produksi susu menggunakan ANCOVA. Hasil penelitian menunjukkan bahwa penambahan MHF memiliki total konsumsi bahan kering yang lebih tinggi $(\mathrm{P}<0,05)$, yaitu $12,99 \pm 0,063 \mathrm{~kg} / \mathrm{ekor} / \mathrm{hari}$ pada R1 dibandingkan dengan R0 sebesar $11.98 \pm 0.295$ kg/ekor/hari. Kecernaan nutrien tidak menurun dengan adanya penambahan konsumsi MHF. Konsumsi energi pada R1 juga lebih tinggi $(P<0,05)$, yaitu $49.95 \pm 0.36 \mathrm{Mkal} / \mathrm{kg}$, dibandingkan dengan $\mathrm{R} 0,46.11 \pm 0.54$ Mkal/kg. Penambahan MHF juga meningkatkan konsumsi nitrogen, konsumsi nitrogen R1 lebih tinggi $(\mathrm{P}<0,05)$, yaitu $318.3 \pm 2.3 \mathrm{~g} / \mathrm{ekor} / \mathrm{hari}$ dibandingkan dengan $\mathrm{R} 0,295.9 \pm 3.5 \mathrm{~g} / \mathrm{ekor} / \mathrm{hari}$, serta dapat mempertahankan persistensi produksi susu pada akhir masa laktasi. Disimpulkan bahwa pemberian MHF sebagai suplemen silase jagung dapat meningkatkan konsumsi bahan kering, konsumsi energi, konsumsi nitrogen, mempertahankan kecernaan nutrien ketika konsumsi bahan kering meningkat, serta mempertahankan persistensi produksi susu sapi perah pada akhir masa laktasi.

Kata kunci: bioslurry, sapi perah, maize hydroponic fodder, kecernaan nutrien

*Corresponding author:

E-mail: permana@ipb.ac.id 


\section{INTRODUCTION}

The accomplishment of milk requirement in Indonesia until now still cannot be satisfied by local dairy farms. This situation affects milk consumption in Indonesia that is lower compared to other countries, even within the Southeast Asian region. Demand for milk and milk products will increase with increasing population growth of $1 \%$ every year, which is the largest of increasing population in developing countries, while the demand for milk and milk products in Indonesia cannot be fulfilled. That situation made Indonesia must import raw milk by $80 \%$ or 2.8 million tons per year (Ditjennak, 2012). There are several factors that cause low milk production in Indonesia. Two of them are dairy cattle's genetic and feed quality. The feed is important in determining the successful of dairy farm business. This is due to feed costs accounted for up to $80 \%$ of total operating costs of dairy farm. The high cost of feed will highly affect the unit cost of output product that is produced, so improving the quality of feed is important to minimize the losses.

Green fodder is an essential component of the dairy nutrition, otherwise the productive and reproductive performances of the dairy animals are adversely affected. Green fodder such as forage is the feed that is required in a dairy farm, because forage containing high fiber increases the production of milk fat due to acetic and butyric acid donations from microbial fermentation. Therefore, for a sustainable dairy farming, quality green fodder should be fed regularly to the dairy animals (Naik et al., 2012). However, the major constraints in production of green fodder by dairy farmers is unavailability of land for fodder cultivation due to small land holding size, scarcity of water or saline water, labor required for cultivation (sowing, earthing up, weeding, harvesting, etc.), requirements of manure and fertilizer, more growth time (approx. 45-60 days), fencing to prevent fodder crops from wild animals and natural calamities, etc. (Naik et al., 2014). Further, the non-availability of quality fodders yearly aggravates the constraints of the sustainable of dairy farming (Naik et al., 2013).

Maize is one of plant that contains abundant of energy on it seeds and produced by-product that potential to be used as a forage. The availability of maize as a forage on land depends on the season. The abundance of forage production during the rainy season and low production of biomass forage in dry season is also become an obstacle in ruminant feed supply, especially in dairy cows. One of many developing preservation techniques is silage. Silage is preserved feed through ensilage process, namely the preservation process feed or forage by using spontaneous fermentation work lactic acid under anaerobic conditions (Despal et al., 2011). Applying silage technology for forage storage is one of the solutions in supplying of forage in dry season, but it also have some disadvantages such as lower nutrient content as a result of microbial degradation activity, and low vitamin, so it requires additional feed.

The effort to improve the quality of silage is through supplementation of maize hydroponic fodder (MHF) which is produced by hydroponic system in greenhouse. MHF is fodder that grown from corn seed in relatively short time by using hydroponic system and vertical farming method. Hydroponics is a technique with vertical planting that uses liquid media for growth, so plant can avoid problems that are often occurred in soil planting. Hydroponic plants have been widely applied by using liquid waste, because these plants can absorb efficiently the components that have been dissolved in the liquid and it is used as plant growth nutrient. One of the waste products that can be used as nutrients in hydroponic plants is bioslurry. Bioslurry is the result of an anaerobic fermentation of organic matter that released by biogas reactor as a by-product after the process of methane production was completed (Nasir et al., 2012).

Utilization of bioslurry as an agricultural fertilizer has not been used widely due to the small amount of biogas installations on a dairy farm as a result of high cost of making biogas reactor. Another obstacle is the high water content of bioslurry so it is difficult to transport and dry. Bioslurry utilization as a fertilizer for MHF can help recycle nutrients and reduce environmental pollution. This study was designed to determine the content of bioslurry as residual gas bio and determine the effect of $7 \%$ MHF addition in corn silage on digestibility and milk production of dairy cows.

\section{MATERIALS AND METHODS}

\section{Production of Corn Silage}

The growth stage of maize used for corn silage was 100 days after planting. The parts of plant that are used are stems, leaves, and corn. Corn silage was enriched with concentrate, molasses, and feed burger sauce (commercial product) to precipitate fermentation process. The corn crop was chopped by using chopper machine, and mixed homogenously with concentrate, molasses and feed burger sauce, $6.37 \%, 0.95 \%, 0.016 \%$ respectively from total weight of silage material, and then inserted into silos (trench silo, with 2 ton capacity), compacted until no air-filled space inside the silo and then closed for 7 days of fermentation. Vacuum condition is very important to speed up the process of anaerobic fermentation and to produce good quality silage.

\section{Preparation of Maize Hydroponic Fodder Fertilizer Solution}

Preparation of nutrient solutions for hydroponic fodder began with the processing of bioslurry from biogas outlet in farm of KPSBU Lembang. Bioslurry derived from reservoirs was taken and then filtered to separate the solids and liquids. After that, it mixed with a liquid mineral fertilizer with a ratio of $25 \%$ bioslurry, and $75 \%$ solution of mineral fertilizers ( $\mathrm{AB}$ mix). The chemical composition of liquid bioslurry is presented on Table 1 .

\section{Planting of Maize Hydroponic Fodder}

Locally available maize (Zea maize $L$ ) seeds that had been sorted were soaked for two days, and then soaked 
Table 1. Chemical composition of liquid bioslurry

\begin{tabular}{ccc}
\hline Nutrient & Unit & Concentration \\
\hline $\mathrm{pH}$ & & 7.02 \\
$\mathrm{BO}$ & $\%$ & 1.15 \\
$\mathrm{C}$-Organik & $\%$ & 0.26 \\
$\mathrm{~N}$ & $\%$ & 0.03 \\
$\mathrm{P}$ & $\%$ & 0.04 \\
$\mathrm{~K}$ & $\%$ & 0.10 \\
$\mathrm{Ca}$ & $\%$ & 0.23 \\
$\mathrm{Mg}$ & $\%$ & 0.05 \\
$\mathrm{~S}$ & $\mathrm{ppm}$ & 15.00 \\
$\mathrm{~B}$ & $\mathrm{ppm}$ & Not detected \\
$\mathrm{Cu}$ & $\mathrm{ppm}$ & 1.34 \\
$\mathrm{Fe}$ & $\mathrm{ppm}$ & 49.47 \\
$\mathrm{Mn}$ & $\mathrm{ppm}$ & 19.76 \\
$\mathrm{Zn}$ & $\mathrm{ppm}$ & 6.60 \\
$\mathrm{As}$ & $\mathrm{ppm}$ & Not detected \\
$\mathrm{Pb}$ & $\mathrm{ppm}$ & 0.003 \\
$\mathrm{Cd}$ & $\mathrm{ppm}$ & 0.008 \\
\hline
\end{tabular}

with hypochloride solution for $15 \mathrm{~min}$ before being planted inside the greenhouse. Seeds soaked with hypochloride were rinsed with clean water and aerated about $10 \mathrm{~min}$ to remove the odor of hypochloride. Seeds were spread in trays that perforated with density of each tray is $0.36 \mathrm{~g} / \mathrm{cm}^{2}$. In the early deployment of corn seed in the tray, the seeds were covered by using a sponge cover to reduce evaporation, so that the seeds would germinate faster. The seed was covered with sponge until five days; began at first planted, and during that time it only sprayed with water. Solution of liquid fertilizer was sprayed on the fifth day until harvesting period by using pressure sprayer evenly on each surface of corn kernels, and it was kept moist, not dried or flooded (Naik et al., 2014).

\section{Harvesting of Maize Hydroponic System}

MHF was harvested at $13 \mathrm{~d}$ after planting. A whole part of plant was harvested and then given as a corn silage ration's supplement for dairy cows. Two days before harvesting, spraying liquid fertilizer was stopped, and replaced with water to remove the liquid fertilizer that attached to plant, so it was safe when it was fed to cattle.

\section{Maintenance of Livestock}

Eight dairy cows on second state of lactation with average milk production approximately $11.36 \pm 2.96 \mathrm{~L} / \mathrm{d}$ were grouped into two levels of daily milk production $(13.44 \pm 2.06 \mathrm{~L} / \mathrm{d}$, and $9.28 \pm 1.69 \mathrm{~L} / \mathrm{d})$. Cows were fed according to the amount of the provision on that farm. MHF supplementation was given to treatment cows before milking as much as $3 \mathrm{~kg}$ fresh matter/head/day or $7 \%$ dry matter. Percentage of feeding and nutrient composition of feed can be seen on Table 2 .
Table 2. Percentage of feeding and nutrient composition

\begin{tabular}{lcc}
\hline \multirow{2}{*}{\multicolumn{1}{c}{ Ration composition }} & \multicolumn{2}{c}{$\begin{array}{c}\text { Percentage of feeding } \\
\text { (\%DM) }\end{array}$} \\
\cline { 2 - 3 } & R0 & R1 \\
\hline Napier grass & 41 & 38 \\
Complete silage ration & 16 & 15 \\
Concentrate & 43 & 40 \\
Maize hydroponic fodder (MHF) & - & 7 \\
Total & 100 & 100 \\
Nutrient composition based on 100\%DM & & \\
Ash & 13.43 & 12.66 \\
Crude protein (CP) & 15.44 & 15.28 \\
Crude fiber (CF) & 24.13 & 22.82 \\
Ether extract (EE) & 3.72 & 3.70 \\
Nitrogen free extract (NFE) & 43.29 & 45.54 \\
Gross energy (kkal/kg) & 3850 & 3877 \\
Total digestible nutrient (TDN) & 58.50 & 60.60 \\
\hline
\end{tabular}

\section{Note:}

Estimation of TDN by Hartadi (1980) formula:

$\mathrm{TDN}=92.464-(3.338 \times \mathrm{CF})-(6.945 \times \mathrm{EE})-(0.762 \times \mathrm{NFE})+(1.115 \times \mathrm{CP})+$ $(0.031 \times \mathrm{CF} 2)-(0.031 \times \mathrm{EE} 2)+(0.036 \times \mathrm{CF} \times \mathrm{NFE})+(0.207 \times \mathrm{EE} \times \mathrm{NFE})+$ $(0.1 \times$ EE $\times \mathrm{CP})-(0.022 \times \mathrm{EE} \times \mathrm{CP})$

R0: Dairy cows that fed with elephant grass, complete silage ration, and concentrate; R1: Dairy cows that fed same with R0 and supplemented with $3 \mathrm{~kg} \mathrm{MHF/head/d} \mathrm{(as} \mathrm{fed).}$

The experiment was carried out for five weeks with two weeks preliminary period. Feed consumption was recorded daily by weighing feeds offered to and refused by the cow. Milking of the animals was performed twice daily at 5.00 am and $3.00 \mathrm{pm}$ by machine milking. At the end of feeding period, digestion trial was conducted on all experimental animals. During the digestion trial, the feeding schedule of the animals remained the same as earlier. The feed residue after $24 \mathrm{~h}$ consumption of each animal was weighed to determine the daily feed intake. Feces were collected quantitatively with total collection method. Feed and feces samples were taken and were analyzed for determination of nutrients (proximate) and energy contents. The contents of nutrients consumed and excreted through feces were measured to calculate the digestibility of nutrients (TDN). Cow's urine was collected for the calculation of nitrogen balance in the same period. Nitrogen balance was calculated by using the formula: $\mathrm{N}$ intake $-\mathrm{N}$ faeces $-\mathrm{N}$ urine $-\mathrm{N}$ milk (Katipana \& Sastradipradja, 1991).

\section{Laboratory Analysis}

Bioslurry content (water content, organic matter, total $\mathrm{N}$ ), nutrient content of feed, feces, and nitrogen on urine were analyzed by using proximate principle (AOAC, 2000), organic carbon by using methods as reported by Olaleye et al. (2014), heavy metals (As, Hg, $\mathrm{Pb}, \mathrm{Cd}), \mathrm{pH}$ bioslurry, macro and micro mineral contents by using spectrophotometer and AAS. Nutrient contents of feed, feces, and urine were analyzed at laboratory of Dairy Nutrition, Faculty of Animal Science, and Biological Resources Research Center and 
Biotechnology, while Gross energy content of feed and feces were analyzed at laboratory of Science and Feed Technology, Faculty of Animal Science. All of laboratories were located at Bogor Agricultural University.

\section{Experimental Design}

This study used a randomized block design with 2 treatment and 4 replications, with treatment as follows:

R0 $=$ cows fed with corn silage + elephant grass + concentrate

$\mathrm{R} 1=\mathrm{R} 0+3 \mathrm{Kg}$ MHF/head/d

Grouping was based on the level of milk production (high and low milk production). The mathematical model used is as follows:

$Y i j=\mu+\alpha i+\beta j+\varepsilon i j$

Yij $=$ Observation on treatment $i$ and replicates $j$

$\mu=$ General mean

$\alpha \mathrm{i}=$ Effect of treatment $\mathrm{i}$

$\beta \mathrm{j}=$ Influence group $\mathrm{j}$

$\varepsilon \mathrm{ij}=$ Error treatment $\mathrm{i}$ and group $\mathrm{j}$

\section{Data Analysis}

The resulting data were analyzed by ANOVA except milk production variables that include variables accompaniment of the initial conditions before the treatment was given using ANCOVA (Analysis of Covariance) (Steel \& Torrie, 1993).

\section{RESULTS AND DISCUSSION}

\section{Bioslurry Content}

Biogas dregs and slurry are by-products of biogas production generated from cattle dung. These residues, especially biogas slurry, are good sources of plant nutrients because the nutrients contained more easily absorbed by the roots of plants. Chemical composition of bioslurry from demo farm biogas reactor at KPSBU Lembang is presented in Table 2.

The contents of the bioslurry were organic carbon and nitrogen value, also many different kinds of minerals, and heavy metals. The content of organic carbon and nitrogen in bioslurry on this study was low enough i.e., $0.26 \%$ and $0.03 \%$ respectively. Therefore, the bioslurry could not be used $100 \%$ as a MHF fertilizer. Studies employing natural abundance carbon (C) and nitrogen $(\mathrm{N})$ isotopes have provided important insights into plant eco-physiology, organic matter cycling, and biogeochemical processes (Ewe et al., 2007; Troxler, 2007) in wetland ecosystems.

Mineral content of bioslurry that was used in this study could be used as a nutrient source MHF, although it was not optimal. In a previous study, bioslurry enriched with $75 \%$ mineral fertilizers (AB Mix) indicated that there was no significant difference as compared with using of $100 \% \mathrm{AB}$ mix (control), so the use of bioslurry could save $25 \%$ of fertilizer cost.

The content of heavy metals in bioslurry such as $\mathrm{As}, \mathrm{Hg}, \mathrm{Pb}$, and $\mathrm{Cd}$ used in this study was not harmful, because the concentrations were fairly small, so it did not inhibit the growth of MHF or poison livestock that consumed MHF.

\section{Dry Matter Intake, Nutrient Digestibility on Dairy Cows}

Feed consumption of each type was same on both treatments (Table 3). The total consumption of both as fed and dry matter was higher in dairy cows receiving MHF as supplementation compared with control treatment (without MHF supplementation) $(\mathrm{P}<0.05)$. This could be caused by a good palatability of MHF, so it could stimulate the increased consumption of other types of feed given. This situation was similar to results reported by Singh \& Chaudry (2007), that the palatability of MHF had a stimulating effect so it could increase consumption.

Consumption of DMI in R1 group was significantly higher than R0 $(\mathrm{P}<0.05)$ (Table 4). This difference was caused by the supplementation of MHF on R1 increased DMI as compared to control. DMI was the most basic and important in animal nutrition, because it determines the amount of nutrients available to the animal for basic living and production. Saijpaul et al. (2005) stated that in milch animals, the total dry matter intake was highly influenced by the daily milk yield and milk composition, which might be up to $15-20 \mathrm{~kg} /$ day.

Determination of dry matter intake is very important in feed evaluation, not only to prevent the deficiency or excess intake of nutrients, but also can assist the use of nutrient efficiently. Deficient intake of nutrients can

Table 3. Feed consumption as fed and dry matter basis

\begin{tabular}{|c|c|c|c|c|}
\hline \multirow{3}{*}{ Feed types } & \multicolumn{4}{|c|}{ Treatment } \\
\hline & \multicolumn{2}{|c|}{ R0 } & \multicolumn{2}{|r|}{$\mathrm{R} 1$} \\
\hline & As fed $(\mathrm{kg} / \mathrm{head} / \mathrm{d})$ & Dry matter $(\mathrm{kg} / \mathrm{head} / \mathrm{d})$ & As fed $(\mathrm{kg} / \mathrm{head} / \mathrm{d})$ & Dry matter $(\mathrm{kg} / \mathrm{head} / \mathrm{d})$ \\
\hline Napier grass & $24.87 \pm 0.204$ & $5.07 \pm 0.042$ & $24.92 \pm 0.144$ & $5.08 \pm 0.029$ \\
\hline Complete silage ration & $13.68 \pm 0.321$ & $1.96 \pm 0.046$ & $13.50 \pm 0.242$ & $1.93 \pm 0.035$ \\
\hline Concentrate & $5.95 \pm 0.337$ & $4.95 \pm 0.280$ & $6.08 \pm 0.058$ & $5.05 \pm 0.048$ \\
\hline Maize hydroponic fodder (MHF) & - & - & $3.00 \pm 0.000$ & $0.92 \pm 0.000$ \\
\hline Total & $44.50 \pm 0.412^{\mathrm{b}}$ & $11.98 \pm 0.295^{\mathrm{b}}$ & $47.49 \pm 0.264^{\mathrm{a}}$ & $12.99 \pm 0.063^{\mathrm{a}}$ \\
\hline
\end{tabular}

Note: Means in the same row with different superscripts differ significantly $(\mathrm{P}<0.05)$. R0= Dairy cows that fed with elephant grass, complete silage ration, and concentrate; R1= Dairy cows that fed same with R0 and supplemented with $3 \mathrm{~kg} \mathrm{MHF/head/d} \mathrm{(as} \mathrm{fed).}$ 
Table 4. Dry matter intake and nutrient consumption on dairy cows $(\mathrm{kg} / \mathrm{head} / \mathrm{d})$

\begin{tabular}{lrc}
\hline \multirow{2}{*}{\multicolumn{1}{c}{ Consumption }} & \multicolumn{2}{c}{ Treatment } \\
\cline { 2 - 3 } & \multicolumn{1}{c}{ R0 } & R1 \\
\hline Dry matter & $11.98 \pm 0.295^{\mathrm{b}}$ & $12.99 \pm 0.063^{\mathrm{a}}$ \\
Organic matter & $10.37 \pm 0.121$ & $11.25 \pm 0.082$ \\
Crude protein & $1.85 \pm 0.022$ & $1.97 \pm 0.014$ \\
Crude fiber & $2.89 \pm 0.034$ & $2.94 \pm 0.021$ \\
Ether extract & $0.44 \pm 0.005$ & $0.47 \pm 0.003$ \\
Nitrogen free extract & $5.26 \pm 0.062$ & $6.07 \pm 0.044$ \\
Dry matter intake & $2.80 \pm 0.110$ & $2.79 \pm 0.040$ \\
(\%Body weight) & & \\
Dry matter intake (NRC, & $2.69 \pm 0.320$ & $2.66 \pm 0.230$ \\
1989) & & \\
\hline
\end{tabular}

Note: Means in the same row with different superscripts differ significantly $(\mathrm{P}<0.05)$. $\mathrm{R} 0=$ Dairy cows that fed with elephant grass, complete silage ration, and concentrate; $\mathrm{R} 1=$ Dairy cows that fed same with R0 and supplemented with $3 \mathrm{~kg}$ MHF/head/d (as fed).

limit the production and can aggravate animal health, while excess intake of nutrients can increase the cost of feed, and on a high level of nutrition provision can lead to poisoning or aggravate animal health (NRC, 2001).

Based on Table 5, it was known that there was no significant difference in nutrient digestibility between R0 and R1. Nutrient digestibility will decrease with increasing of dry matter intake because it can cause the increase rate of passage. However, in this experiment, MHF supplementation that could improve dry matter intake could reduce the rate of passage in rumen, so there was no declining of digestibility when dry matter intake was increased. Protein digestibility in cows supplemented with MHF (R1) was higher than the previous study i.e., $72.6 \%$ in dairy cows supplemented with MHF (Naik et al., 2014).

\section{Digestible Energy}

Based on Table 6, dairy cows fed with MHF had higher energy consumptions and significantly different from control $(\mathrm{P}<0.05)$. This difference was affected by the

Table 5. Dry matter and nutrient digestibility on dairy cows

\begin{tabular}{lcc}
\hline \multirow{2}{*}{\multicolumn{1}{c}{ Digestibility (\%) }} & \multicolumn{2}{c}{ Treatment } \\
\cline { 2 - 3 } & R0 & R1 \\
\hline Dry matter & $76.0 \pm 8.99$ & $77.0 \pm 4.24$ \\
Organic matter & $78.0 \pm 8.49$ & $78.5 \pm 3.99$ \\
Crude protein & $83.0 \pm 6.27$ & $82.6 \pm 3.35$ \\
Ether extract & $91.5 \pm 3.86$ & $90.9 \pm 1.68$ \\
Nitrogen free extract & $76.0 \pm 9.01$ & $76.9 \pm 4.14$ \\
Total digestible nutrient & $71.8 \pm 7.52$ & $72.7 \pm 3.54$ \\
\hline
\end{tabular}

Note: TDN was counted based on Sutardi (1980): OM able to digest $+1.25 \mathrm{EE}$ able to digest. R0= Dairy cows that fed with elephant grass, complete silage ration, and concentrate; R1= Dairy cows that fed same with R0 and supplemented with $3 \mathrm{~kg}$ MHF/head/d (as fed). energy content of ration on R1 that was higher than R0, in addition to the effect of higher DMI in R1 group.

The energy excreted through feces on both groups of treatments showed that there was no significant difference. This non-significant difference could be caused by differences in the amount of feces that were excreted by cows on each treatment, so that the multiplier factor in determining the amount of energy that comes out can be influential. It can be seen in Table 6 that the average of feces energy on R1 tended to be higher than R0, so it can be interpreted that the amount of energy that excreted through feces was also greater in R1. The value of digestible energy (DE) in Table 6 was also showed that there was no significant difference $(\mathrm{P}>0.05)$, so that it could be said that cows given MHF or not had the same energy digestibility. Digestible energy was associated with DMI, which increasing of DE value of feed will reduce DMI, but it had a very weak relationship with milk production (Phuong et al., 2013).

\section{Nitrogen Balance}

Nitrogen consumption on R0 was lower and significantly different compared with R1 $(\mathrm{P}<0.05)$ (Table 7). The amount of nitrogen excreted through feces and urine on R0 also had lower scores and significantly different compared with R1. Based on Table 7, the consumption of nitrogen on dairy cows at R1 was significantly different and higher than R0 ( $<<0.05)$. This could be caused by DMI on R1 was higher although

Tabel 6. Energy consumption, feces energy, digestible energy on dairy cows

\begin{tabular}{lcc}
\hline \multirow{2}{*}{ Variables } & \multicolumn{2}{c}{ Treatment } \\
\cline { 2 - 3 } & $\mathrm{R} 0$ & $\mathrm{R} 1$ \\
\hline Dry matter intake (kg/head/d) & $11.98 \pm 0.295^{\mathrm{b}}$ & $12.99 \pm 0.063^{\mathrm{a}}$ \\
Energy consumption & $46.11 \pm 0.54^{\mathrm{b}}$ & $49.95 \pm 0.36^{\mathrm{a}}$ \\
(Mkal/kg) & & \\
Feces energy (Mkal/kg) & $10.35 \pm 4.07$ & $10.72 \pm 1.44$ \\
Digestible energy (Mkal/kg) & $2.99 \pm 0.33$ & $3.05 \pm 0.11$ \\
\hline
\end{tabular}

Note: Means in the same row with different superscripts differ significantly $(\mathrm{P}<0.05)$. R0= Dairy cows that fed with elephant grass, complete silage ration, and concentrate; R1= Dairy cows that fed same with R0 and supplemented with $3 \mathrm{~kg} \mathrm{MHF} / \mathrm{head} / \mathrm{d}$ (as fed).

Table 7. Nitrogen balance (g/head/d)

\begin{tabular}{lcc}
\hline \multirow{2}{*}{ Variables } & \multicolumn{2}{c}{ Treatment } \\
\cline { 2 - 3 } \multicolumn{1}{c}{ R0 } & R1 \\
\hline N Intake & $295.9 \pm 3.5^{\mathrm{b}}$ & $318.3 \pm 2.3^{\mathrm{a}}$ \\
N Feces & $44.7 \pm 16.8$ & $48.8 \pm 9.6$ \\
N Urin & $54.4 \pm 4.9^{\mathrm{b}}$ & $84.4 \pm 14.9^{\mathrm{a}}$ \\
N Milk & $48.2 \pm 9.3$ & $55.0 \pm 6.8$ \\
Nitrogen balance & $148.7 \pm 23.1$ & $130.1 \pm 13.3$ \\
\hline
\end{tabular}

Note: Means in the same row with different superscripts differ significantly $(\mathrm{P}<0.05)$. R0= Dairy cows that fed with elephant grass, complete silage ration, and concentrate; R1= Dairy cows that fed same with R0 and supplemented with $3 \mathrm{~kg}$ MHF/head/d (as fed). 
the percentage of nitrogen on ration R1 was lower than R0. The higher DMI consumption, the higher nitrogen excreted in urine and feces on R1 was higher than R0 $(\mathrm{P}<0.05)$. The consumption of nitrogen was affected by milk production. This research showed that when milk production was higher, the nitrogen consumption was also higher. This result was appropriate with Ipharraguerre \& Clark (2005) that showed there was increasing nitrogen intake when milk production was increased if the rumen degradable protein and rumen undegradable protein were properly matched with the source and amount of carbohydrate in the diet.

The amount of nitrogen secreted in the milk of the two treatments groups showed that there were no significant difference, but R1 had higher nitrogen content in the milk, which might result in higher protein content in the milk. The high content of protein in milk could be caused by protein contribution of MHF on ration $(11.97 \%)$, but it was lower than previous study $(13.30 \%)$ (Naik et al., 2014). Almost all of the remaining nitrogen in the body of dairy cow was excreted through the feces and urine (NRC, 2001).

Nitrogen contained in the urine of R1 cows was higher than R0. This difference could be affected by nitrogen intake in R1 group that was higher than in R0. This result was similar to the result of previous study that stated that there was a linear effect of dietary crude protein concentration, ranging from 135 to $194 \mathrm{~g} / \mathrm{kg}$ DM (Colmenero \& Broderick, 2006).

\section{Milk Production}

The mean of daily milk production on R0 and R1 was not significantly different (Table 8 ). This nonsignificant effect on milk production could be caused by the stage of lactation in all experimental dairy cows that was in the declined stage at the end of the study period. The nonsignificant difference in milk production could also be due to the similar contents of crude protein in ration fed to R0 and R1 groups i.e., $15.03 \%$ and $14.84 \%$ respectively. Some studies reported that there was no increase in milk production, milk protein content, DMI, and total solid when the feed protein content was increased (Voltolini et al., 2010; Pereira et al., 2010).

There was an alteration between the initial amounts of milk production with the average daily production during the period of observation (Table 8). Cows in R1 group had a smaller rate of milk production decline as

Table 8. Daily milk production (L/d)

\begin{tabular}{lll}
\hline \multirow{2}{*}{\multicolumn{1}{c}{ Period }} & \multicolumn{2}{c}{ Milk production } \\
\cline { 2 - 3 } & \multicolumn{1}{c}{ R0 } & \multicolumn{1}{c}{ R1 } \\
\hline Before research & $12.70 \pm 3.62$ & $13.33 \pm 2.66$ \\
Daily production on research & $10.88 \pm 3.21$ & $11.84 \pm 2.16$ \\
Alteration $(\Delta)$ & $1.82 \pm 1.38$ & $1.49 \pm 1.16$ \\
\hline
\end{tabular}

Note: $\mathrm{R} 0=$ Dairy cows that fed with elephant grass, complete silage ration, and concentrate; R1= Dairy cows that fed same with R0 and supplemented with $3 \mathrm{~kg} \mathrm{MHF/head/d} \mathrm{(as} \mathrm{fed).}$ compared with cows in R0 i.e., $1.49 \mathrm{~L} / \mathrm{d}$ and $1.82 \mathrm{~L} / \mathrm{d}$ respectively. It can be interpreted that supplementation of MHF can maintain the persistency of milk production efficiently. Phuong et al. (2013) stated that feed efficiency in dairy cow production was an important factor that must be considered because feed does not only affect profits but also affect environment in terms of sewage. If the nutrients that consumed were not converted into milk, food reserves of the body, or to the development of fetal bovine, the nutrients will be excreted into environment, which produces emissions, such as ammonia, methane or nitrous oxide (Thomassen et al., 2009).

\section{CONCLUSION}

Supplementation of maize hydroponic fodder using bioslurry as a fertilizer for corn silage's supplement on dairy cows increases dry matter intake, energy consumption, and nitrogen consumption, also can maintain nutrient digestibility and maintain persistency of milk production during late lactation.

\section{REFERENCES}

AOAC. 2000. Official Methods of Analysis, 17th Ed. Association of Official Analytical Chemists, Washington DC, USA.

Colmenero, J. J. O., \& G. A. Broderick. 2006. Effect of dietary crude protein concentration on milk production and nitrogen utilization in lactating dairy cows. J. Dairy Sci. 89: 17041712. http://dx.doi.org/10.3168/jds.S0022-0302(06)72238-X

[Ditjennak] Direktorat Jenderal Peternakan. 2012. Bersama membangun persusuan nasional. http://ditjennak.pertanian.go.id/berita-337-bersama-membangun-persusuannasional.html.

Despal, I. G. Permana, S. N. Safarina, \& A. J. Tatra. 2011. Penggunaan berbagai sumber karbohidrat terlarut air untuk meningkatkan kualitas silase daun rami. Med. Pet. 34: 6976. http://dx.doi.org/10.5398/medpet.2011.34.1.69

Ewe, S. M. L., L. d. S. L. Sternberg, \& D. L. Childers. 2007. Seasonal plant water uptake patterns in the saline southeast Everglades ecotone. Oecologia. 152: 607-616. http://dx.doi. org/10.1007/s00442-007-0699-x

Ipharraguerre, I. R. \& J. H. Clark. 2005. Varying protein and starch in the diet of dairy cows. II. Effects on performance and nitrogen utilization for milk production. J. Dairy Sci. 88: 3219-3229. http://dx.doi.org/10.3168/jds.S00220302(05)72932-5

Katipana N. \& D. Sastradipradja. 1991. Neraca nitrogen dan energi pada kambing menyusui dan tidak menyusui yang mendapat ransum tambahan ubi kayu yang dimasak dan urea. J Hemera Zoa.72: 25-35.

Naik, P. K., R. B. Dhuri, B. K. Swain, M. Karunakaran, E. B. Chakurkar, \& N. P. Singh. 2013. Analysis of existing dairy farming in Goa. Indian Journal of Animal Sciences 83: 299303.

Naik, P. K., R. B. Dhuri, M. Karunakaran, B. K. Swain, \& N. P. Sing. 2014. Effect of feeding hydroponics maize fodder on digestibility of nutrients and milk production in lactating cows. Indian Journal of Animal Science. 84: 880-883.

Naik, P. K., B. K. Swain, E. B. Chakurkar, \& N. P. Singh. 2012. Performance of dairy cows on green fodder maize based rationin coastal hot and humid climate. Animal Nutrition and Feed Technology 12: 265-70.

Nasir, A., M. U. Khalid, S. Anwar, C. Arslan, M. J. Akhtar, \& M. Sultan. 2012. Evaluation on bio-fertilizer application to ameliorate the environment and crop production. Pak. J. Agri. Sci. 49: 527-531. 
National Research Council. 2001. Nutrient Requirements of Dairy Cattle 7th Rev. Ed. Washington, D.C (US): National Academy Press.

Olaleye, A. O., T. Nkheloane, R. Mating, K. Mahlako, K. Rathebe, F. Letsika, \& M. G. Rasekoele. 2014. Wetlands in Khalong-la-Lithuiya catchment in Lesotho: Soil organic carbon contents, vegetation isotopic signatures and hydrochemistry. Catena. 115: 71-78. http://dx.doi.org/10.1016/ j.catena.2013.11.018

Pereira, F. R., H. M. Saturnino, E. O. S. Saliba, L. C. Gonçalves, R. B. Reis, P. A. B. Miranda, R. C. Mourão, D. T. Silvetre, \& P. N. S. Caldeira. 2009. Protein contents for lactating cows grazing elephant grass. Braz. J. Vet. Anim. Sci. 61: 1139-1147.

Phuong, H. N., N. C. Friggens, I. J. M. De Boer, \& P. Schmidely. 2013. Factors affecting energy and nitrogen efficiency of dairy cows: A meta-analysis. J Dairy Sci. 96:7245-7259. http://dx.doi.org/10.3168/jds.2013-6977

Saijpaul, S., R. S. Grewal, R. Kaur, \& P. K. Naik. 2005. Evaluation of some potential complete rations for economic milk production in crossbred cows. Anim. Nutr. Feed Tech. 5: 203-210
Singh, B., \& J. L. Chaudary. 2007. Effect of different levels of maize fodder on the performance of crossbred heifers. Indian Journal of Animal Nutrition. 24: 256-257.

Steel R. G. D., \& J. H. Torrie. 1993. Prinsip dan Prosedur Statistika Suatu Pendekatan Biometrik. Penerjemah: Sumantri B. Ed ke-3. Gramedia, Jakarta.

Thomassen, M. A., M. A. Dolman, K. J. Van Calker, \& I. J. M. De Boer. 2009. Relating life cycle assessment indicators to gross value added for Dutch dairy farms. Ecol Econ. 68:2782284. http://dx.doi.org/10.1016/j.ecolecon.2009.02.011

Troxler, T.G. 2007. Patterns of phosphorus, nitrogen and d15N along a peat development gradient in a coastal mire, Panama. J. Trop. Ecol. 23: 683-691. http://dx.doi.org/10.1017/ S0266467407004464

Voltolini, T. V. F. A. P. Santos, J. C. Martinez, H. Imaizumi, R. L. Clarindo, \& M. A. Penati. 2010. Milk Producion and composition of dairy cows grazing elephant grass under two grazing intervals. Braz. J. Anim. Sci. 39: 121-127. 